\title{
Bryophyte community diversity and structure associated with Asplenium auritum fern (Aspleniaceae) in a Brazilian Atlantic forest fragment
}

\author{
Libia Mayerly Cifuentes-García ${ }^{1 *}$, Pedro Manuel Villa ${ }^{2}$, Denilson Fernandes Peralta ${ }^{3} \&$ \\ Pedro Bond Schwartsburd ${ }^{1}$ \\ 1. Universidade Federal de Viçosa, Departamento de Biologia Vegetal, Programa de Pós-Graduação em Botânica, CEP: \\ 36570-900, Viçosa, MG, Brasil; pedro.schw@ufv.br, libiacifuentes1986@gmail.com \\ 2. Universidade Federal de Viçosa, Departamento de Engenharia Florestal, CEP: 36570-900, Viçosa, MG, Brasil; \\ pedro.villa@ufv.br \\ 3. Instituto de Botânica, Núcleo de Pesquisa em Briologia, Caixa Postal 68041, CEP: 04045-972 São Paulo, SP, Brasil; \\ denilsonfperalta@gmail.com \\ * Correspondence
}

Received 21-VIII-2019. C Corrected 21-XII-2019. Accepted 23-II-2020.

\begin{abstract}
Introduction: Local environmental filters have shown the influence on the bryophyte diversity and structure communities, but there are limited studies that analyze how biotic relationships filters influence these communities. Objective: To evaluate whether the influence of fern Asplenium auritum cover determine changes in species richness and composition of bryophyte communities, in a semideciduous remnant forest, Minas Gerais, Brazil. Methods: We selected one transect of $300 \mathrm{~m}$ in each of six areas where Asplenium auritum was present. In all transect we estimated plant cover in $3910 \times 10 \mathrm{~cm}$ plots randomly distributed. We compare the estimated species richness and composition of bryophyte between fern coverage levels. Results: We found 60 species in 35 genera and 23 families. Weft and mat were the most represented life-forms. Fern cover had no significant effect on bryophyte species richness and composition. Conclusions: Bryophyte cover appears to improve fern development and promote the coexistence of several bryophyte species. Bryophyte cover probably predicts variations in species richness and drives the species assemblage in this community.
\end{abstract}

Key words: fern, interactions, liverworts, mosses, plant cover.

Cifuentes-García, L. M., Villa, P. M., Fernandes Peralta, D., \& Bond Schwartsburd, P. (2020). Bryophyte community diversity and structure associated with Asplenium auritum fern (Aspleniaceae) in a Brazilian Atlantic forest fragment. Revista de Biología Tropical, 68(1), 230-241.

One of the main issues of ecological studies is to understand how biotic and abiotic drivers shape plant community assemblages along environmental gradients (Götzenberger et al., 2012). Two major factors determine plant community assemblages, environmental filters (e.g., elevation, growth substrates) and limiting similarity (e.g., biotic interactions). Limiting similarity implies that low niche overlap between two species will allow their coexistence (Götzenberger et al., 2012). Under environmental filtering, habitat restrictions result in the establishment of species with similar environmental requirements (e.g., Mudrák et al., 2016). When habitat filtering is the major driver, some species with similar environmental requirements may limit the presence of one another in the community (Götzenberger et 
al., 2012). Most plant community assemblage studies in the Brazilian Atlantic Forest have evaluated the effect of environmental drivers (e.g. elevation, soil properties) on species richness and community composition, mainly in vascular plant communities (e.g., Neri et al., 2016; Rodrigues, Villa, \& Viana, 2019; Silva et al., 2019). Some studies recognize altitude, temperature, substrate availability and microhabitat as important filters of tropical bryophyte diversity (Amorim, Carvalho, Santos, \& Luizi-Ponzo, 2017; Peñaloza-Bojacá et al., 2018; Silva, Sfair, Santos, \& Pôrto, 2018), while there is little knowledge about the biotic interactions and mechanisms that affect the structure of bryophyte communities (Zamfir \& Goldberg, 2000; Mulder, Uliassi, \& Doak, 2001; Benavides, 2007).

The composition and structure of bryophyte communities have been considered the result of environmental conditions, and interactions with other organisms, such as the effect of vascular plants on competition and facilitation (Mulder et al., 2001; Benavides, 2007). Studies indicate a positive relationship between rupicolous and courticolus bryophytes with some ferns (Dubuisson, Hennequin, Rakotondrainibe, \& Schneider, 2003; Ellyson \& Sillett, 2003). For the Atlantic Forests of Brazil, Sylvestre (2001) mentions the development of Asplenium auritum, on bryophyte-covered rocks and trunks located near streams.

The Atlantic Forest is recognized as a biodiversity hotspot with a high percentage of endemic species (Stehmann et al., 2009). Unfortunately, it is under intensive process of deforestation and destruction, and only ca. $10 \%$ of the original area persists as isolated fragments in different stages of succession (Costa \& Lima, 2005). Still, the Atlantic Forest fragments are important maintainers of biodiversity, with a positive relationship between biodiversity and ecosystem functioning (Rodrigues et al., 2019).

Bryophytes represent one of the important functional groups in the maintenance of the diversity and structure in the Atlantic Forest (Costa \& Gomes, 2003). Studies in this phytogeographic domain in Southeastern Brazil shown the influence of local environmental filters (physical and chemical characteristics of substrates, environment temperature and water availability) on the cover and composition of bryophyte species in these communities (Amorim et al., 2017; Batista \& Santos, 2016). However, there are limited studies that analyze how biotic relationships filters shape communities of bryophytes in the Atlantic Forest.

In this study we evaluate whether the influence of fern Asplenium auritum cover determine changes in species richness and composition of bryophyte communities, in a semideciduous remnant forest in the Parque Estadual da Serra do Brigadeiro (State of Minas Gerais, Brazil). We addressed the following questions: (1) what is species richness and community composition pattern of bryophytes associated with A auritum? (2) What is the species cover distribution of bryophyte communities associated with A. auritum? (3) Does fern cover affect bryophyte species richness? This is the first study of biotic interactions between the bryophyte communities and a fern species in a remnant of the Atlantic Forest in Southeastern Brazil.

\section{MATERIALS AND METHODS}

Study area: Our study was developed in the Parque Estadual da Serra do Brigadeiro (PESB), a protected area under state administration, located in the state of Minas Gerais, Brazil (2043'57.1" S \& 42²8'09.8” W; Fig. 1). The PESB covers an area of 14985 ha and is inserted in the Atlantic Forest phytogeographic domain, and has two types of plant formations, according with IBGE (2012): (1) Semideciduous forest from the altomontana formation, and (2) high-altitude fields (campos de altitude). The climate is mesothermal $(\mathrm{CWb})$ in Koeppen's (1948) classification, with an average temperature of $18{ }^{\circ} \mathrm{C}$ and a minimum of less than $0{ }^{\circ} \mathrm{C}$ in the highest areas, and an annual average rainfall of $1500 \mathrm{~mm} /$ year, with a dry period from June to August (PESB, 2007). 


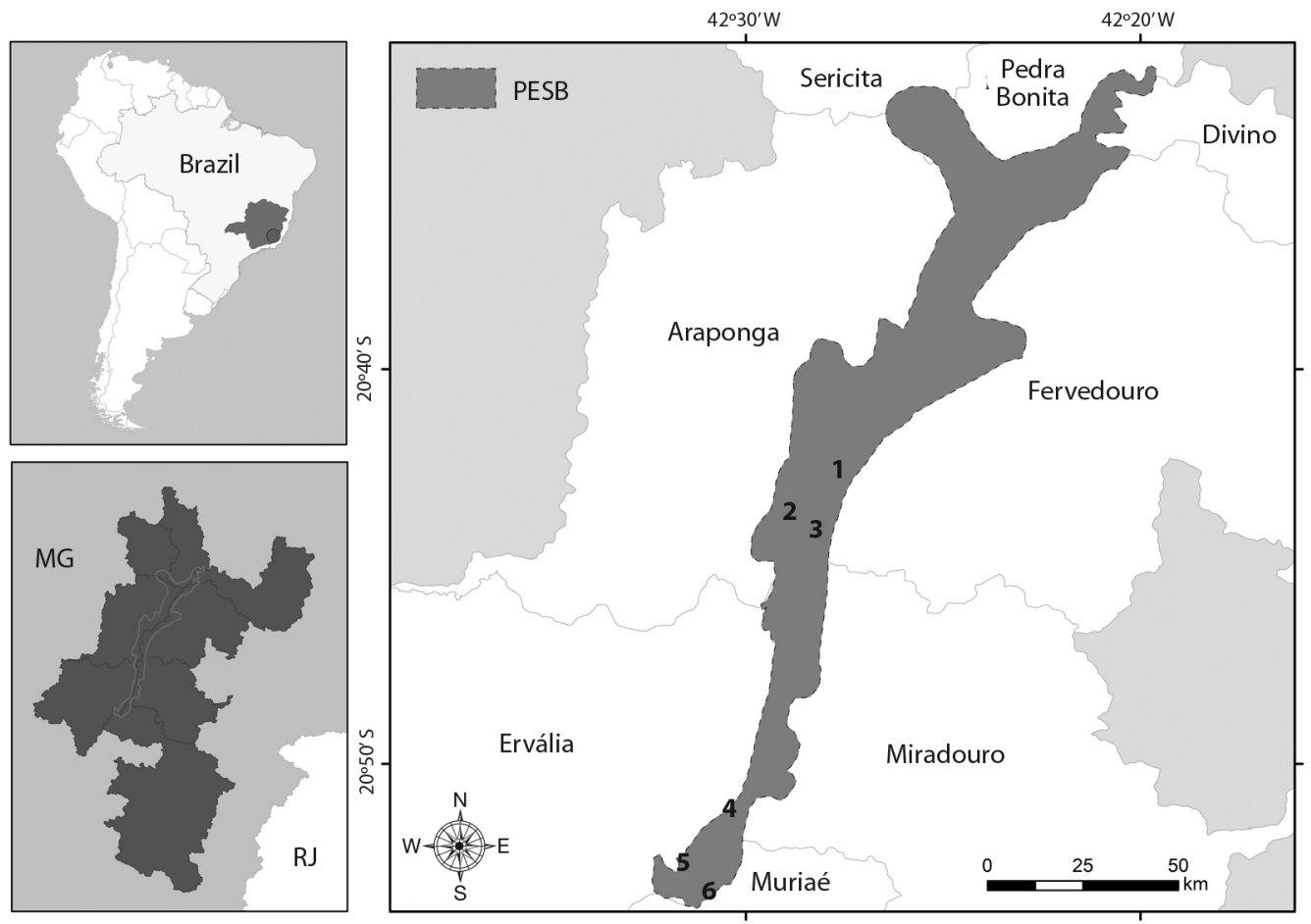

Fig. 1. Location of the study sites within Parque Estadual da Serra do Brigadeiro (PESB), Minas Gerais, Brazil: (1) Trilha do Carvão, (2) Trilha do Pico do Grama, (3), Trilha da Pedra do Pato (4) Trilha do Cruzeiro do Careço, (5) Trilha do Itajurú e (6) Trilha do Avião. South America and Brazilian map with the Minas Gerais State (gray map) and the boundaries of PESB. Map generated using ArcGIS ${ }^{\circledR}$.

We worked in the semideciduous forest (Oliveira-Filho \& Ratter, 1995) along six sites distributed in the middle and Southern sectors of the PESB (Fig. 1). These areas correspond to vegetation cover located mainly on the mountain slopes, between 1000 and $1360 \mathrm{~m}$ of elevation, and the predominant vegetation is characterized by secondary forests in various stages of succession (Caiafa \& Silva, 2005).

Vegetation sampling: Plant measurements and collections were carried out during four expeditions between May 2017 and April 2018. We selected one transect of $300 \mathrm{~m}$ in each of six areas where Asplenium auritum was present. In all transect we established $3910 \times$ $10 \mathrm{~cm}$ plots randomly distributed, divided into 25 subplots $2 \times 2 \mathrm{~cm}$. Each plot was located in the middle of each substrate occupied by the fern for estimated plant cover (Garcia-Cancel,
Melédez-Ackerman, Olaya-Arenas, Flores, \& Tremblay, 2013) and identification of bryophyte species. From each plot, all bryophytes were identified to the species level. We recorded A. auritum cover and represented in four fern cover levels $(25,50,75$ and $100 \%)$. All bryophytes were collected for later re-identification in the VIC Herbarium.

Bryophyte identification: Species identification included the preparation of slides and observation in stereo- and optical microscope, using keys and specialized literature (Sharp, Crum, \& Eckel, 1994; Gradstein, Churchill, \& Salazar-Allen, 2001; Gradstein \& Costa, 2003; Costa, Almeida, Santos, Gradstein, \& Churchill, 2010; Yano \& Peralta, 2011; Bordin \& Yano, 2013). All specimens are deposited in the herbarium VIC (Acronym follows Index Herbariorum, Thiers, 2019). Our classification 
follows Söderström et al. (2016) for Marchantiophyta and Goffinet, Buck, and Shaw (2009) and Carvalho-Silva et al. (2017) for Bryophyta. Eight types of bryophyte life-forms were recognized (Mägdefrau, 1982): cushion, fan, dendroid, mat, pendant, turf, thalloid and weft.

Data analysis: To compare bryophyte species richness between four fern cover levels and between mosses and liverworts, we used sample-based data to estimate rarefaction and extrapolation curves, using the first Hill number (Chao et al., 2014). Extrapolations were made based on presence/absence of species in the plot data, using Hill's number of order 0 (Colwell et al., 2012). These estimates were obtained using the "iNEXT" package (Hsieh, Ma, \& Chao, 2016).

Non-metric multidimensional scaling (NMDS) and permutational multivariate analysis of variance (PERMANOVA, 9,999 permutations) were performed using 'Vegan' package (Oksanen et al., 2017) to determine the differences in species composition between four fern cover levels.

The species rank curves were based on plant cover. To obtain species rank curves, all species were ranked from the most to the least dominant ones based in cover (e.g.
Villa et al., 2018). Finally, we tested the main effects of bryophyte cover, and fern cover level on bryophyte species richness, using a covariance analysis (ANCOVA). Variables were grouped into three categories, viz. bryophyte species richness (continuous response variable) at community level (overall species); and fern and bryophyte cover (continuous explanatory variable).

\section{RESULTS}

Floristic composition and life-forms: We found a total of 60 species (30 liverworts and 30 mosses), grouped in 35 genera and 23 families (Table 1). Among liverworts, families Lejeuneaceae and Plagiochilaceae stood out as the richest, with 15 and five species, respectively. The richest moss families were Fissidentaceae and Pilotrichaceae, with four species each. The most representative genera in the liverworts were Lejeunea, with eight species, and Plagiochila with five; for mosses, Fissidens, with four species was the most speciose genus.

Among the eight life-forms recorded, weft had the highest species richness, with 28 (47 $\%)$, followed by mat, with 14 (23\%), turf and fan with five each $(8 \%)$, whereas only one

TABLE 1

List of bryophytes species in the Parque Estadual da Serra do Brigadeiro, Minas Gerais, Brazil, frequency in sample plots and life-forms

\begin{tabular}{lcc}
\multicolumn{1}{c}{ Species } & Frequency & Life-form \\
Mosses & & Mat \\
Brittonodoxa subpinnata (Brid.) W.R. Buck, P.E.A.S.Câmara \& Carv.-Silva & 1 & Turf \\
Campylopus arctocarpus (Hornsch.) Mitt. & 2 & Weft \\
Chryso-hypnum diminutivum (Hampe) W.R.Buck & 5 & Weft \\
Chryso-hypnum elegantulum (Hook.) Hampe & 1 & Weft \\
Cyclodictyon albicans (Hedw.) Kuntze & 1 & Weft \\
Eulacophyllum cultelliforme (Sull.) W.R.Buck \& Ireland & 1 & Fan \\
Fissidens dissitifolius Sull. & 1 & Fan \\
Fissidens hornschuchii Mont. & 7 & Fan \\
Fissidens pellucidus Hornsch. & 1 & 1 \\
Fissidens zollingeri Mont. & 1 & Fan \\
Isopterygium subbrevisetum (Hampe) Broth. & 1 & Mat \\
Isopterygium tenereum (Sw.) Mitt. & 1 & Mat \\
Isopterygium tenerifolium Mitt. & & Mat \\
\hline
\end{tabular}


TABLE 1 (Continued)

\begin{tabular}{|c|c|c|}
\hline Species & Frequency & Life-form \\
\hline Leiomela bartramioides (Hook.) Paris & 2 & Turf \\
\hline Lepidopilum muelleri (Hampe) Mitt. & 1 & Mat \\
\hline Lepidopilum scabrisetum (Schwägr.) Steere & 1 & Mat \\
\hline Leucobrym crispum Müll. Hal. & 1 & Cushion \\
\hline Pelekium schistocalyx (Müll.Hal.) A. Touw & 1 & Weft \\
\hline Plagiomnium rhynchophorum (Hook.) T.J.Kop. & 7 & Mat \\
\hline Porotrichum longirostre (Hook.) Mitt. & 1 & Dendroide \\
\hline Pyrrhobryum spiniforme (Hedw.) Mitt. & 1 & Turf \\
\hline Racopilum tomentosum (Hedw.) Brid. & 8 & Mat \\
\hline Rhynchostegium serrulatum (Hedw.) A.Jaeger & 3 & Mat \\
\hline Syrrhopodon prolifer Schwägr. & 1 & Turf \\
\hline Thamniopsis langsdorffii (Hook.) W.R. Buck & 3 & Mat \\
\hline Thuidium tomentosum Schimp. & 4 & Mat \\
\hline Tortella humilis (Hedw.) Jenn. & 1 & Turf \\
\hline Vitalia cuspidifera (Mitt.) P.E.A.S. Câmara, Carv.-Silva \& W.R.Buck & 1 & Mat \\
\hline Vitalia galipensis (Müll. Hal.) P.E.A.S. Câmara, Carv.-Silva \& W.R.Buck & 1 & Mat \\
\hline Zelometeorium patulum (Hedw.) Manuel & 1 & Pendant \\
\hline \multicolumn{3}{|l|}{ Liverworts } \\
\hline Bryopteris filiciana (Sw.) Nees & 1 & Pendant \\
\hline Cheilolejeunea clausa (Nees \& Mont.) R.M.Schust. & 2 & Weft \\
\hline Cheilolejeunea rigidula (Nees ex Mont.) R.M. Schust. & 1 & Weft \\
\hline Cryptolophocolea martiana (Nees) L. Söderstr., Crand.-Stotler \& Stotler & 5 & Weft \\
\hline Drepanolejeunea orthophylla (Nees \& Mont.) Bischl. & 1 & Weft \\
\hline Lejeunea bermudiana (A.Evans) R.M.Schust. & 3 & Weft \\
\hline Lejeunea caulicalyx (Steph.) E.Reiner \& Goda & 1 & Weft \\
\hline Lejeunea cristulata (Steph.) E.Reiner \& Goda & 3 & Weft \\
\hline Lejeunea flava (Sw.) Nees & 3 & Weft \\
\hline Lejeunea laetevirens Nees \& Mont. & 2 & Weft \\
\hline Lejeunea oligoclada Spruce & 1 & Weft \\
\hline Lejeunea pterigona (Lehm. \& Lindenb.) Mont. & 2 & Weft \\
\hline Lejeunea sp.1 & 1 & Weft \\
\hline Lejeunea sp.2 & 1 & Weft \\
\hline Lophocolea bidentata (L.) Dumort & 5 & Weft \\
\hline Lophocolea muricata (Lehm.) Nees & 1 & Weft \\
\hline Metzgeria albinea Spruce & 1 & Thalloid \\
\hline Metzgeria conjugata Lindb. & 4 & Thalloid \\
\hline Metzgeria fruticola Spruce & 1 & Thalloid \\
\hline Neurolejeunea breutelii (Gottsche) A.Evans & 2 & Weft \\
\hline Plagiochila corrugata (Nees) Nees \& Mont. & 1 & Pendant \\
\hline Plagiochila patentissima Lindenb. & 1 & Weft \\
\hline Plagiochila patula (Sw.) Lindenb. & 1 & Weft \\
\hline Plagiochila rutilans Lindenb. & 10 & Weft \\
\hline Plagiochila subplana Lindenb. & 1 & Weft \\
\hline Porella reflexa (Lehm. \& Lindenb.) Trevis. & 1 & Mat \\
\hline Radula javanica Gottsche & 1 & Fan \\
\hline Radula nudicaulis Steph. & 5 & Weft \\
\hline Telaranea diacantha (Mont.) Engel \& Merr. & 1 & Weft \\
\hline
\end{tabular}


species was found as cushion and another as dendroid (Table 1). The more frequent species in the samples were, Plagiochila rutilans, found in ten samples, Racopilum tomentosum, in eight, and Plagiomnium rhynchophorum and Fissidens hornschuchii, found in seven samples each (Table 1).

Species richness and community composition: The accumulated richness in relation to the sample units presented similar trends between different cover levels of Asplenium auritum, with significant differences $(\mathrm{P}<0.05)$. The species accumulation curve tended to stabilize the asymptote approximately from the 50th sample units under different cover levels of $A$. auritum (Fig. 2). The NMDS did not show differences in floristic composition among the bryophyte communities with different cover levels of A. auritum (Stress-Euclidean $=0.16$; $\mathrm{F}_{3.33}=0.97$; $\mathrm{P}>0.51$ ) (Fig. 3). When analyzing the floristic grouping of plots by fern cover levels, high levels of similarity (Fig. 4).
Effects of cover on species richness: Fern cover (Ancova, $\mathrm{F}_{1,70}=0.50 ; \mathrm{P}>0.92$ ) did not have significant effects on species richness.

Species cover distribution: The distribution of the bryophyte species cover through the dominance-diversity curve showed Plagiochila rutilans as the dominant species in the study area (12\% cover), followed by Racopilum tomentosum (9\%) and Chrysohypnum diminutivum (6\%), which accumulated the highest cover values in the samples evaluated. Telaranea diacantha and Lejeunea oligoclada were the species with the lowest cover values in the samples, with only $0.06 \%$ each (Fig. 5).

\section{DISCUSSION}

The Atlantic Forest is the region with the greatest diversity of bryophytes in Brazil, with $71 \%$ of the taxa recognized for the country (Costa, 2009); thus the high species richness (60) recorded in this study, in a total sampled

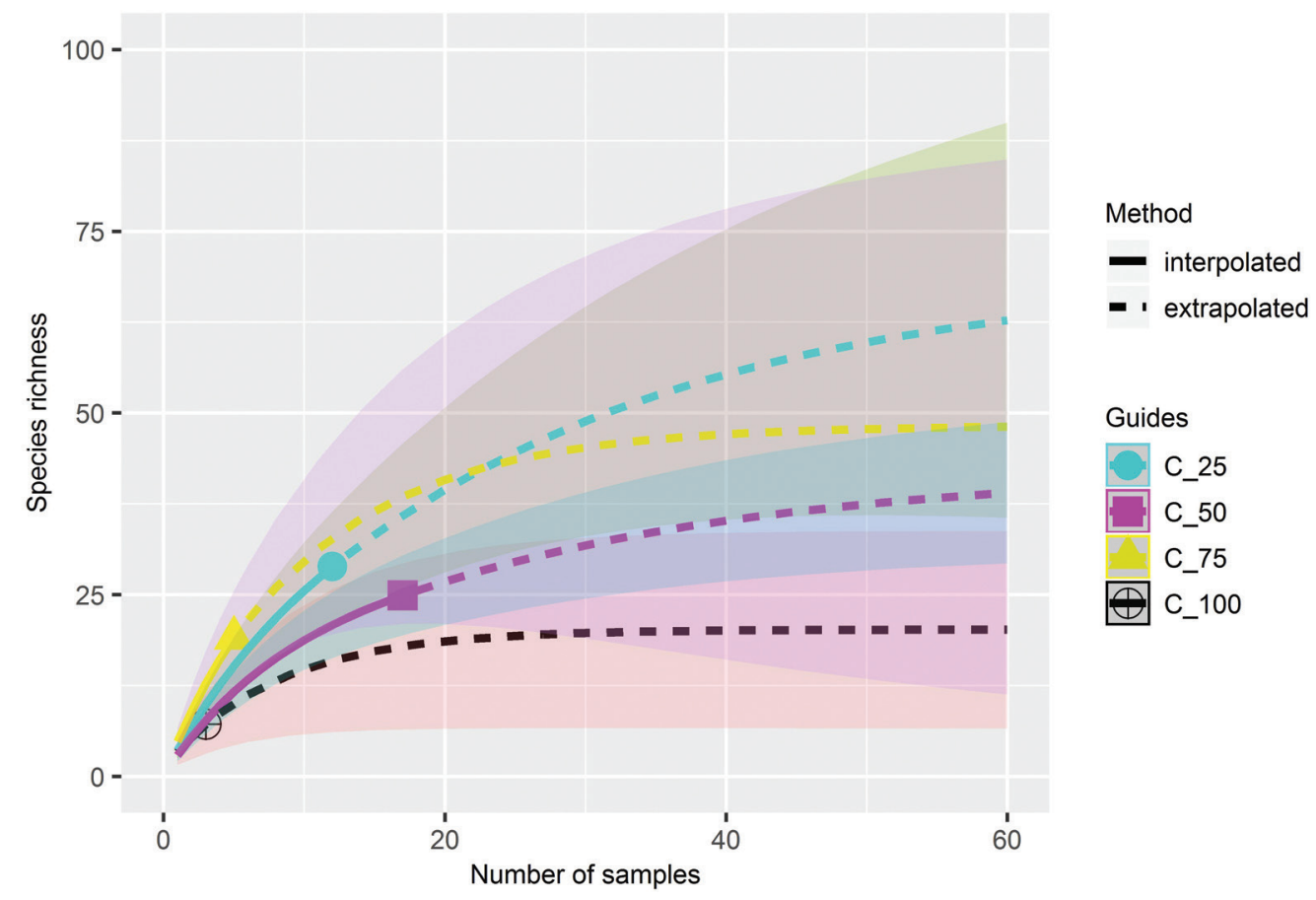

Fig. 2. Rarefaction curve of bryophytes at the Parque Estadual da Serra do Brigadeiro, Minas Gerais, Brazil, based on number of sample units with different $A$. auritum levels cover. 


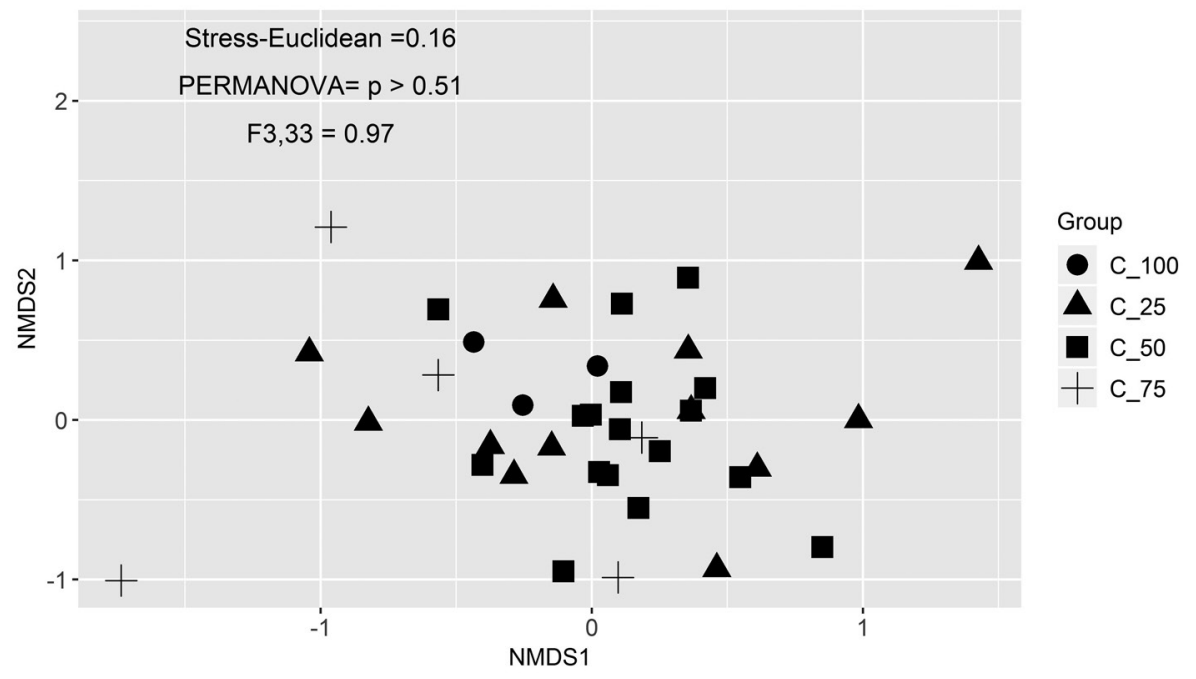

Fig. 3. Non-parametric multidimensional scaling (NMDS) representing species composition among samples of bryophytes evaluated under different $A$. auritum levels cover at the Parque Estadual da Serra do Brigadeiro, Minas Gerais, Brazil.

area of less than $50 \mathrm{~m}^{2}$, comes as no surprise. This high diversity has been explained by different ecological processes in the Atlantic Domain, with a long geological history, a favorable climate, a higher source of native species (see, e.g., Frahm, 2003; Stehmann et al., 2009).

The genera and families found in this study have been commonly recorded in other Atlantic Forest surveys (Gradstein \& Costa, 2003; Costa, 2009; Costa \& Peralta, 2015). Lejeuneaceae (25\% of all species) was the most representative family in a number of species in the sampled areas, as expected since it is the most diverse family in Brazil (Costa \& Peralta, 2015).

Bryophyte life-forms are related to the availability of light and moisture in the environment (Mägdefrau, 1982). The high representativeness of weft species $(47 \%)$ in the studied community can be explained in relation to their capacity to retain considerable amounts of water for long periods of time -capillarity-, which favors their proliferation in areas with high luminosity, high air humidity, and dry periods, such as those of the microhabitats sampled. Santos and Costa (2008) found a high number of weft and turf species occurring as corticolous and rupicolous in forest and stream border microhabitats, as is the case of the areas sampled in this study.

The accumulation curve showed that our sampling provided a reasonable representation of the richness for the area evaluated. This result was consistent with the stabilization trend of the asymptote $(\mathrm{N}=50)$, close to the number of samples evaluated $(\mathrm{N}=39)$. Our results also suggest that the accumulated richness in relation to sample units is not affected by the different cover levels of Asplenium auritum. In addition, the NMDS showed that floristic composition did not change significantly having high similarity between plots, which was probably due to biotic relationships or limitation by dispersion, and not by environmental filter influence.

These results suggest that the cover and richness of the bryophyte species could favor the establishment and growth of A. auritum. Facilitative interaction, like the maintenance of higher humidity by the bryophyte species, as a result of their life-forms (weft and mat), and the full contact with the substrate (Silva et al., 2018), would favor the development of 

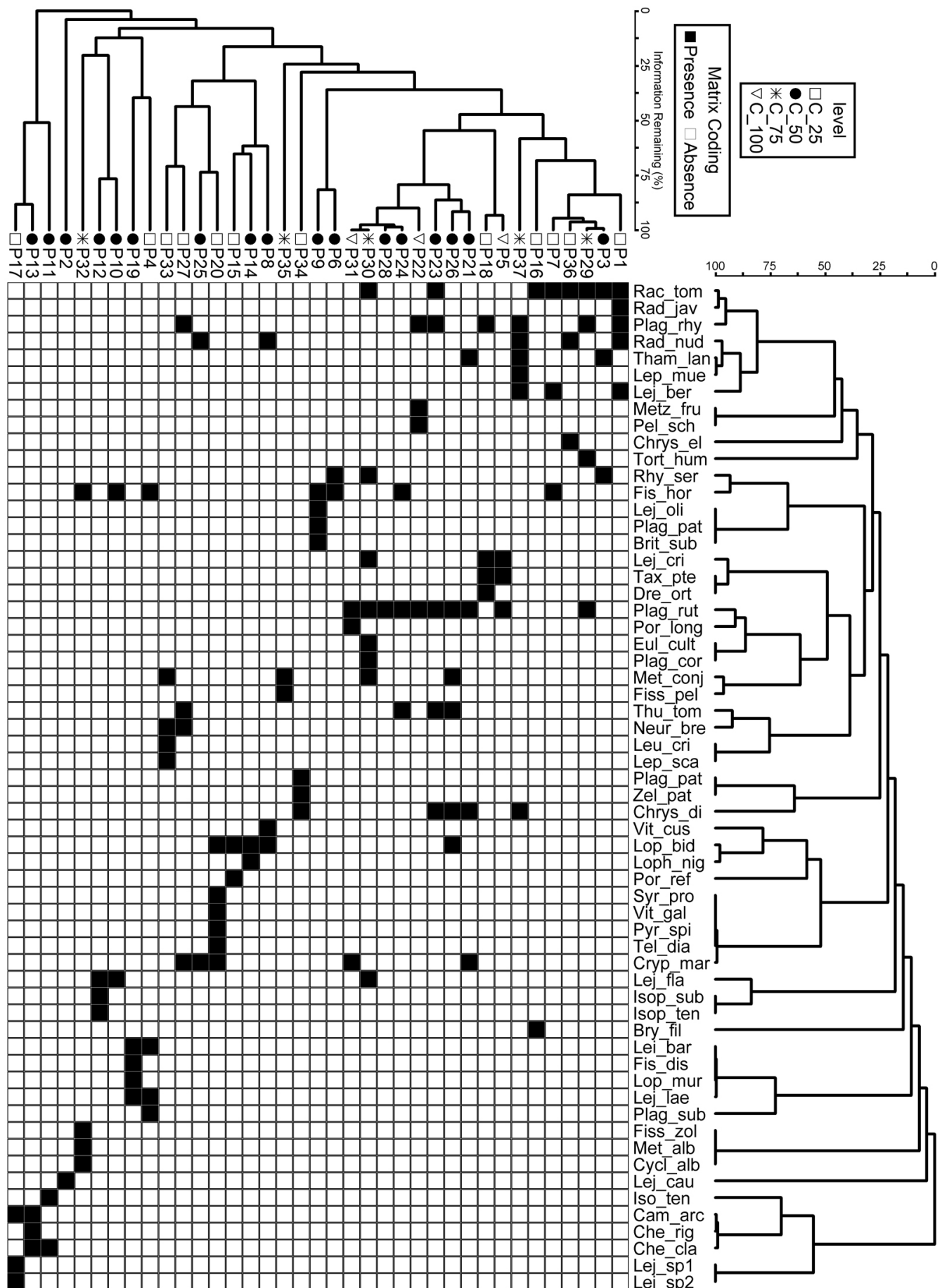

Rac tom

Rad_jav

Plag_rhy

Rad_nud

Tham_lan

Lej_ber

Metz_fru

Pel sch

Chrys_el

ony-ser

Fis hor

Lej_oli

Plaggpat

Brit sub

Lej_cri

Tax_pte

Por Tong $\square$

Eul_cult

Plaḡ_cor

Met_conj

Thu tom

Neur bre

Leu_cri

ep_sca

Plag_pat

Chrys di

Vit_cus

op_bid

Por_ref

Syr_pro

Vit_gal.

Cryp mar

Lej_fla

sop_sub

Bry fil

Lei_bar

op mur

Lej Tae

Plaggsub

Fiss_zol

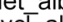

cyci alb

Lej_cal

Cam arc

Che rig

Che-cla

Lej_sp1

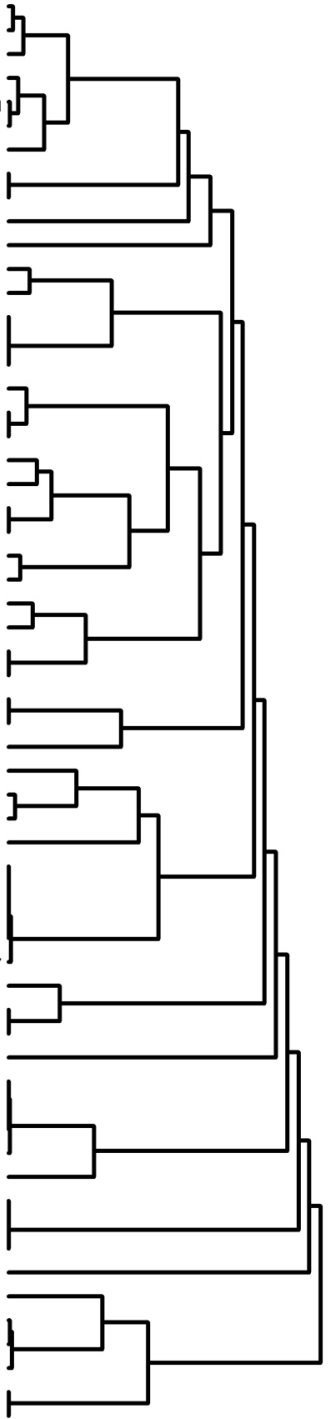

Fig. 4. Dendrogram of floristic similarity between bryophyte plots distributed in different fern cover levels based on presence-absence matrix (Euclidean distance). 


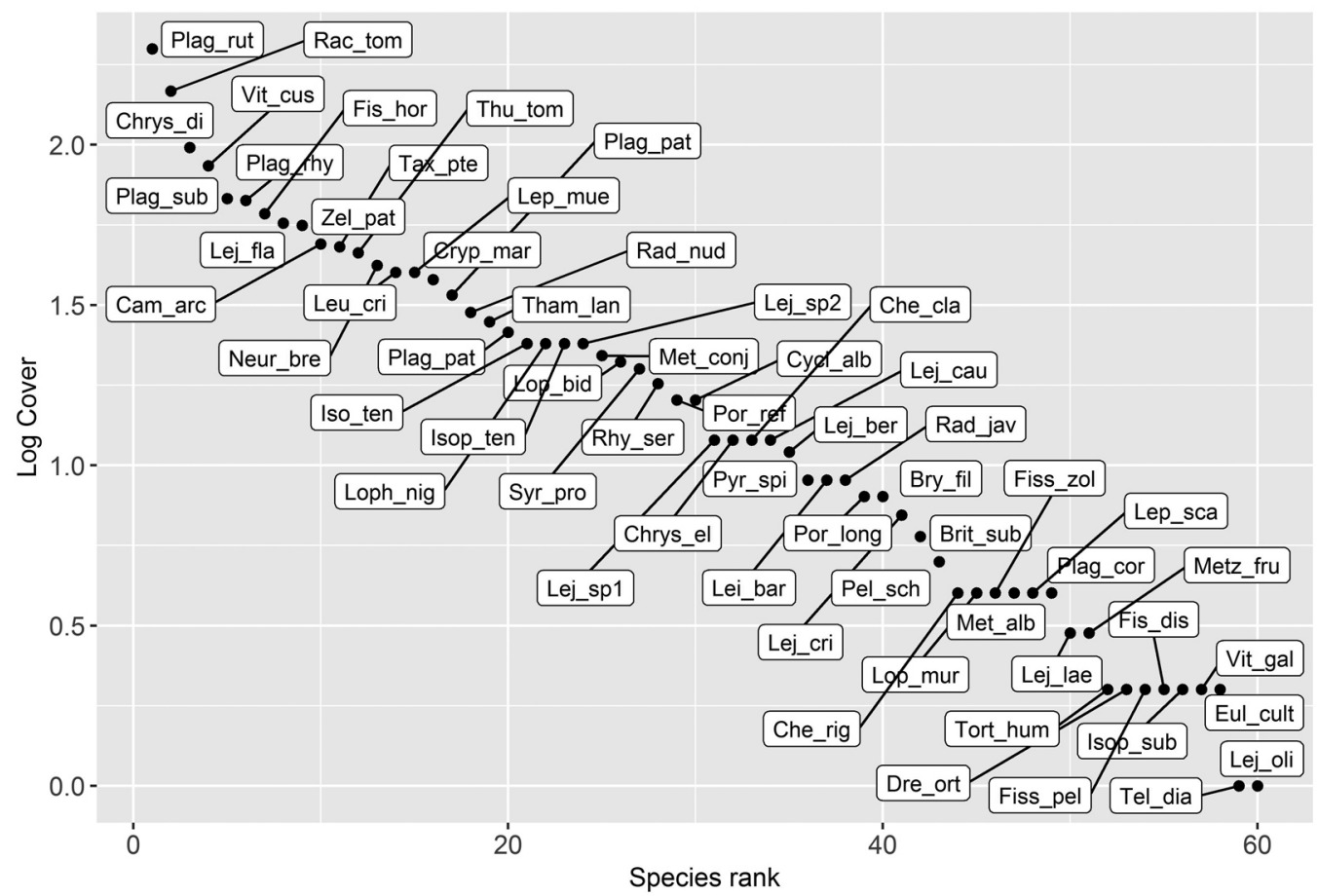

Fig. 5. Dominance-diversity curve of bryophytes. Cover distribution of bryophyte species ("y" axis) through species composition (each species is present on the " $\mathrm{x}$ " axis).

adventitious buds along the fern stolons, and consequently promote the formation of shoots in different stages of development. According to Sylvestre (2001), A. auritum propagates vegetatively through stolons, forming continuous populations in carpets, with sporophytes of different sizes, in some cases in the first stages of development.

Other authors also found an association between bryophytes and ferns. Pócs (1982) mentioned bryophytes, both rupicolous and corticolous, growing frequently associated with Hymenophyllaceae ferns, whereas Dubuisson et al. (2003) and Ellyson and Sillett (2003) reported fern gametophyte and adult seedling development in the midst of bryophyte cover, and suggested such cover was a potential facilitator of spore germination and establishment of gametophytes for some pteridophytes.

The bryophyte species cover had a positive relation with species richness. Sanaei, Ali, Chahouki and Jafari (2018) explained how high vegetation density produces niche differentiation, promotes species coexistence and niche facilitation processes between rare and abundant species (Carrión, Gastauer, Mota, \& Meira-Neto, 2017). We observed bryophyte communities dominated by Plagiochila rutilans, Racopilum tomentosum and Chrysohypnum diminutivum with high cover values (Fig. 5), and morpho-ecological characters related to an increase of the water absorption surface and resistance to desiccation (Glime, 2006). This, in turn, favors the colonization of more exposed habitats and survival during periods of drought (Parolly \& Küschner, 2005). It would probably generate a microhabitat that favors the coexistence of a high number of species with lower cover values, like Telaranea diacantha and Lejeunea oligoclada, more sensitive to environmental changes and requiring a close association with the above-mentioned species, in order to develop. 
Bryophytes are poikilohydric -quickly absorb water over the entire surface and lose it in the same way-, so density (cover) is relevant because this should favor shoot growth and reduce evapotranspiration (Proctor, 1982). This suggests that facilitative effects are predominant (Zamfir \& Goldberg, 2000). Consequently, bryophyte cover could determine variations in species richness of the community and presumably could drive the species assembage. Thus, vegetation cover is a mechanism linking high species diversity with a high production of biomass in the ecosystems as a whole, as suggested by Sanaei et al. (2018).

In conclusion, our results suggest that, contrary to our initial assumption, in the PESB, A. auritum cover does not affect species richness and composition or cover of the bryophyte communities. Bryophyte cover could possibly improve fern development and promote the coexistence of dissimilar bryophyte species, although this should be confirmed by further research.

Ethical statement: authors declare that they all agree with this publication and made significant contributions; that there is no conflict of interest of any kind; and that we followed all pertinent ethical and legal procedures and requirements. All financial sources are fully and clearly stated in the acknowledgements section. A signed document has been filed in the journal archives.

\section{ACKNOWLEDGMENTS}

We thank CAPES (Coordenação de Aperfeiçoamento de Pessoal de Nível Superior) for the scholarships granted to the first author, and IEF (Instituto Estadual de Florestas, Minas Gerais) for the sampling permission. Pedro M. Villa thanks CNPq (Conselho Nacional de Desenvolvimento Científico e Tecnológico) for postdoctoral scholarships. We also thank the director of the Park José Roberto Mendes de Oliveira and other park staff, for logistics, transportation and assistance during the field trips. We greatly appreciate the help in the field of Julio Lanazca Vargas and Nayara S. Smith Braga.

\section{RESUMEN}

Diversidad y estructura de la comunidad de briófitos asociada con el helecho Asplenium auritum (Aspleniaceae) en un fragmento del bosque atlántico brasileño. Introducción: Los filtros ambientales locales ejercen influencia en la diversidad y en la estructura de las comunidades de briófitas, pero existen pocos estudios que analicen cómo las relaciones bióticas influyen en estas comunidades. Objetivo: Evaluar la influencia de la cobertura del helecho Asplenium auritum sobre los cambios en la riqueza de especies y la composición de las comunidades briófitos, en un bosque remanente semideciduo en Minas Gerais, Brasil. Métodos: Seleccionamos un transecto de $300 \mathrm{~m}$ en cada una de las seis áreas donde A. auritum estaba presente. En cada transecto, estimamos la cubierta vegetal en 39 parcelas de $10 \times 10 \mathrm{~cm}$ distribuidas al azar. Comparamos la riqueza estimada de especies y la composición de briófitos entre los niveles de cobertura del helecho. Resultados: Encontramos 60 especies en 35 géneros y 23 familias. Las formas de vida más representativas fueron las de tipo trama y estera. Los diferentes niveles de cobertura del helecho no mostraron efecto significativo sobre la riqueza de especies y la composición de las comunidades de briófitos. Conclusiones: La cobertura de briófitos parece favorecer el desarrollo del helecho, podría promover la coexistencia de varias especies de briófitos y podría predecir variaciones en la riqueza de especies e impulsar el ensamble de especies en esta comunidad.

Palabras clave: helecho, interacciones, hepáticas, musgos, cobertura vegetal.

\section{REFERENCES}

Amorim, E., Carvalho, F.A., Santos, N.D., \& Luizi-Ponzo, A.P. (2017). Distribution of bryophytes in SouthEastern Brazil: An approach on floristic similarity and environmental filtering. Cryptogamie Bryologie, 38(1), 3-17.

Batista, W.V.S.M., \& Santos, N.D. (2016). Can regional and local filters explain epiphytic bryophyte distributions in the Atlantic Forest of Southeastern Brazil? Acta Botanica Brasilica, 30(3), 462- 472.

Benavides, J.C. (2007). Competitive ability of an epilithic moss, Thuidium tomentosum Schimp., under different light treatments in a subtropical lower montane forest in Puerto Rico (Master's Thesis). University of Puerto Rico, Mayagüez campus.

Bordin, J., \& Yano, O. (2013). Fissidentaceae (Bryophyta) do Brasil. Boletim do Instituto de Botânica, 22, 1-72. 
Caiafa, A., \& Silva, A. (2005). Composição florística e espectro biológico de um campo de altitude no Parque Estadual da Serra do Brigadeiro, Minas Gerais - Brasil. Rodriguésia, 56(87), 163-173.

Carrión, J.F., Gastauer, M., Mota, N.M., \& Meira-Neto, J.A.A. (2017). Facilitation as a driver of plant assemblages in Caatinga. Journal of Arid Environments, 142, 50-5.

Carvalho-Silva, M., Stech, M., Soares-Silva, L.H., Buck, W.R., Wickett, N.J., Liu, Y., \& Câmara, P.E.A.S. (2017). A molecular phylogeny of the Sematophyllaceae s.l. (Hypnales) based on plastid, mitochondrial and nuclear markers, and its taxonomic implications. Taxon, 66(4), 811-831.

Chao, A., Gotelli, N.J., Hsieh, T.C., Sander, E.L., Ma, K.H., Colwell, R.K., \& Ellison, A.M. (2014). Rarefaction and extrapolation with Hill numbers: A framework for sampling and estimation in species diversity studies. Ecological Monograph, 84(1), 45-67.

Colwell, R.K., Chao, A., Gotelli, N.J., Lin, S.Y., Mao, C.X., Chazdon, R.L., \& Longino, J.T. (2012). Models and estimators linking individual-based and sample based rarefaction, extrapolation and comparison of assemblages. Journal of Plant Ecology, 5(1), 3-21.

Costa, D.P. (2009). Briófitas. In J.R. Stehmann, R.C. Forzza, A. Salino, M. Cabral, D.P. Costa, \& L.H.Y. Kamino (Eds.), Plantas da Floresta Atlântica (pp. 13-17). Rio de Janeiro: Jardim Botânico do Rio de Janeiro.

Costa, D.P., Almeida, J.S.S., Santos, N.D., Gradstein, S.R., \& Churchill, S.P. (2010). Manual de Briologia. Rio de Janeiro: Interciencia.

Costa, D.P., \& Gomes, A. (2003). Briófitas da Reserva Natural da Vale do Rio Doce, Linhares, Espírito Santo, Brasil. Boletim do Museu de Biologia, Mello Leitao (NSér), 16, 21-38.

Costa, D.P., \& Lima, F.M. (2005). Moss diversity in the tropical rainforests of Rio de Janeiro, Southeastern Brazil. Revista Brasileira de Botânica, 28(4), 671-685.

Costa, D.P., \& Peralta, D.F. (2015). Bryophytes diversity in Brazil. Rodriguésia, 66(4), 1063-1071.

Dubuisson, J.Y., Hennequin, S., Rakotondrainibe, F., \& Schneider, H. (2003). Ecological diversity and adaptive tendencies in the tropical fern Trichomanes L. (Hymenophyllaceae) with special reference to climbing and epiphytic habits. Botanical Journal of the Linnean Society, 142(1), 41-63.

Ellyson, W.J.T., \& Sillett, S.C. (2003). Epiphyte communities on Sitka Spruce in an Old-Growth Redwood Forest. The Bryologist, 106(2), 197-211.

Frahm, J.P. (2003). Manual of tropical bryology. Tropical Bryology, 23, 1-196.
García-Cancel, J.G., Melédez-Ackerman, E.J., Olaya-Arenas, A.M., Flores, N.P., \& Tremblay, R.L. (2013). Associations between Lephantes rupestris Orchids and bryophytes presence in the Luquillo Experimental Forest, Puerto Rico. Caribbean Naturalist, $4,1-14$.

Glime, J.M. (2006). Bryophyte Ecology (1 ${ }^{\text {th }}$ ed.). [Ebook]. Michigan, U.S: Janice M. Glime.

Goffinet, B., Buck, W.R., \& Shaw, A.J. (2009). Morphology, anatomy and classification of the Bryophyta. In B. Goffinet \& A.J. Shaw (Eds.), Bryophyte Biology ( $2^{\text {nd }}$ ed., pp. 13-17). Cambridge: Cambridge University Press.

Götzenberger, L., Bello, F., Bråthen, K.A., Davison, J., Dubuis, A., Guisan, A., ... Zobel, M. (2012). Ecological assembly rules in plant communities-approaches, patterns and prospects. Biological Reviews, 87(1), 111-127.

Gradstein, S.R., Churchill, S.P., \& Salazar-Allen, N. (2001). Guide to the bryophytes of tropical America. Bronx, N.Y.: New York Botanical Garden Press, U.S.

Gradstein, S.R., \& Costa, D.P. (2003). The Hepaticae and Anthocerotae of Brazil. N.Y., U.S.: New York Botanical Garden Pr Dept, U.S.

Hsieh, T.C., Ma, K.H., \& Chao, A. (2016). iNEXT: iNterpolation and EXTrapolation for species diversity (R package version 2.0.12). Retrieved from https:// cran.r- project.org/web/packages/iNEXT/iNEXT.pdf

IBGE (Instituto Brasileiro de Geografia e Estatística) (2012). Manual técnico da vegetação brasileira. Rio de Janeiro, Brasil: Instituto Brasileiro de Geografia e Estatística - IBGE.

Koeppen, W. (1948). Climatología. México D.F, México: Fondo de Cultura Económica.

Mägdefrau, K. (1982). Life-forms of bryophytes. In A.J. Smith (Eds.), Bryophyte ecology (pp. 45-58). London: Chapman and Hall.

Mudrák, O., Janeček, S., Götzenberger, L., Mason, N.W.H., Horník, J., Castro, I., ... Bello, F. (2016). Fine-scale coexistence patterns along a productivity gradient in wet meadows: shifts from trait convergence to divergence. Ecography, 39(3), 338-348.

Mulder, C.P.H., Uliassi, D.D., \& Doak, D.F. (2001). Physical stress and diversity-productivity relationships: The role of positive interactions. Proceedings of the National Academy of Sciences, 98(12), 6704-6708.

Neri, A.V., Borges, G.R.A., Meira-Neto, J.A.A., Magnago, L.F.S., Trotter, I.M., Schaefer, C.E.G.R., \& Porembski, S. (2016). Soil and altitude drives diversity and functioning of Brazilian Páramos (campo de altitude). Journal of Plant Ecology, 10(5), 731-743. 
Oksanen, J., Blanchet, F.G., Friendly, M., Kindt, R., Legendre, P., McGlinn, D., ... Wagner, H. (2017). Vegan: Community Ecology Package ( $\mathrm{R}$ package version 2.0-2). Retrieved from https:/github.com/ vegandevs/vegan

Oliveira-Filho, A., \& Ratter, J. (1995). A study of the origin of Central Brazilian Forests by the analysis of plant species distribution patterns. Journal of Botany, 52(2), 141-194.

Parolly, G., \& Kurschner, H. (2005). Syntaxonomy, life forms, life strategies and ecomorphology of the subandean woodlands and Polylepis forests in Central Ecuador. Ecosociological studies in Ecuadorian bryophyte communities. VI. Botanische Jahrbücher, 126(2), 211-252.

Peñaloza-Bojacá, G.F., Oliveira, B.A., Araújo, C.A.T., Fantecelle, L.B., Santos, N.D., \& Maciel-Silva, A.S. (2018). Bryophytes on Brazilian ironstone outcrops: Diversity, environmental filtering, and conservation implications. Flora, 238, 162-174.

PESB (Parque Estadual da Serra do Brigadeiro) (2007). Plano de manejo Parque Estadual da Serra do Brigadeiro. Governo do Estado de Minas Gerais. Secretaria de Estado de Meio Ambiente e Desenvolvimento Sustentável - SEMAD.

Pócs, T. (1982). Tropical forest bryophytes. In A.J.E., Smith (Ed.), Bryophyte ecology. (pp. 59-103). London, UK: Chapman and Hall.

Proctor, M.C.F. (1982). Physiological ecology: water relations, light, and temperature responses, carbon balance. In A.J.E. Smith (Ed.), Bryophyte Ecology (pp. 333-381). London, UK: Chapman \& Hall.

Rodrigues, A.C., Villa, P.M., \& Viana, A.N. (2019). Finescale topography shape richness, community composition, stem and biomass hyperdominant species in Brazilian Atlantic forest. Ecological Indicator, 102, 208-217.

Sanaei, A., Ali, A., Chahouki, M.A.Z., \& Jafari, M. (2018). Plant coverage is a potential ecological indicator for species diversity and aboveground biomass in semi-steppe rangelands. Ecological Indicators, 93, 256-266.

Santos, N.D., \& Costa, D.P. (2008). A importância de reservas particulares do patrimônio natural para a conservação da brioflora da Mata Atlântica: um estudo em El Nagual, Magé, RJ, Brasil. Acta Botanica Brasilica, $22,359-372$
Sharp, A.J., Crum, H., \& Eckel, P. (1994). The Mosses flora of Mexico. N.Y., U.S.: Botanical Garden $\mathrm{Pr}$ Dept, U.S.

Silva, J.B., Sfair, J.C, Santos, N.D., \& Pôrto, K.C. (2018). Bryophyte richness of soil islands on rocky outcrops is not driven by island size or habitat heterogeneity. Acta Botanica Brasilica, 32(2), 161-168.

Silva, W.A., Villa, P.M., Schaefer, C.E.G.R., Ferreira Júnior, W.G., Campos, P.V., Fialho, I.F., \& Neri, A.V. (2019). Diversity and life-forms of a woody herbaceous community on the quartzite rocky complexes in the Brazilian Iron Quadrangle. Revista de Biología Tropical, 67(3), 357-369.

Söderström, L., Hagborg, A., Konrat, M., BartholomewBegan, S., Bell, D., Briscoe, L., ... Zhu, R.L. (2016). World checklist of hornworts and liverworts. PhytoKeys, 59,1-828.

Stehmann, J.R., Forzza, R.C., Salino, A., Sobral, M., Costa, D.P., \& Kamino, L. (2009). Plantas da Floresta Atlântica. Rio de Janeiro, Brasil: Jardim Botânico do Rio de Janeiro.

Sylvestre, L. (2001). Revisão taxonômica das espécies da família Aspleniaceae A.B. Frank ocorrentes no Brasil (Ph.D. Dissertation). Universidade de São Paulo, São Paulo.

Thiers, B. (2019). Index Herbariorum: A Global Directory of Public Herbaria and Associated Staff. New York Botanical Garden's Virtual Herbarium. Retrieved from http://sweetgum.nybg.org/science/ih

Villa, P.M., de Siqueira Cardinelli, L., Magnago, L.F., Heringer, G., Martins, S.V., Campos, P.V., ... MeiraNeto, J.A.A. (2018). Relación especie-área y distribución de la abundancia de especies en una comunidad vegetal de un inselberg tropical: efecto del tamaño de los parches. Revista de Biología Tropical, 66(2), 937-951.

Yano, O., \& Peralta, D.F. (2011). Flora da Serra do Cipó, Minas Gerais: Briófitas (Anthocerotophyta, Bryophyta e Marchantiophyta). Boletim de Botânica da Universidade de São Paulo, 29(2), 135-211.

Zamfir, M., \& Goldberg, D.E. (2000). The effect of initial density on interactions between bryophytes at individual and community levels. Journal of Ecology, 88(2), 243-255. 